The concepts of the rhetorical competence of the teacher and the professionally oriented rhetorical competence of the future teacher are defined. The necessity of theoretical bases and practical ways of formation of the rhetorical competence of future teachers in pedagogical colleges is substantiated.

Key words: future teacher, rhetoric, competence approach, a competence, rhetorical competence, rhetorical competence of the teacher, pedagogical college.

DOI: $10.32626 / 2309-9763.2019-26-1.42-46$

Ліна Голуб, Євгенія Шаповал Lina Holub, Evheniia Shapoval

МЕТОДОЛОГІЯ ФОРМУВАННЯ ПРОФЕСІЙНОЇ ДИНАМІЧНОСТІ ТА ЇЇ ЗНАЧЕННЯ В ПРОЦЕСІ СТАНОВЛЕННЯ КОМПЕТЕНТНОСТІ ВЧИТЕЛЯ ФІЗИЧНОЇ КУЛЬТУРИ

\title{
METHODOLOGY OF FORMING PROFESSIONAL DYNAMISM AND ITS VALUE IN THE PROCESS OF FORMATION OF PHYSICAL CULTURE TEACHER'S TRAINING
}

Автори статті досліджують проблему розвитку професійної компетентності майбутнього вчителя фізичної культури на основі формування їхньої професійної мобільності. У статті проаналізовано сучасний стан педагогічної підготовки фахівия, ї зміст і методичне забезпечення; розглянуто специфіку професійної діяльності вчителя фізичної культури; облрунтовано методологічні основи та виявлено ступінь розробленості проблеми; вивчено вітчизняний $i$ зарубіжний досвід підготовки майбутніх учителів до спортивно-педагогічної діяльності в навчально-виховному процесі.

Узагальнення наукових поглядів учених увиразнює те, що сучасному фахівцеві доводиться вирімувати завдання, які не мали аналогів у минулому, що вимагає сбормованості в нвого аналітичних, інформаційних, реблексивних, периептивних, комунікативних та інших умінь. 3 огляду на це, окреслено актуальність підготовки компетентного фахівия, який володіє основами професійної динамічності.

Ключові слова: професійні компетентності; педагогічна технологія; вчитель фізичної культури; динамічність; педагогічні умови; технологічність процесу.

Мінливість технологій професійної діяльності, службових функцій, зростання потоків інформації і необхідність із ними працювати, розширення творчого змісту праці, швидке старіння “освітнього капіталу” висувають принципово нові вимоги до кваліфікації фахівців, ïx моральної зрілості, загальнокультурного та інтелектуального рівнів.

Тому сьогодні вища освіта повинна не лише забезпечувати фундаментальну наукову, професійну та практичну підготовку, здобуття майбутніми фахівцями освітньо-кваліфікаційного рівнів відповідно до їх інтересів та здібностей, удосконалення професійної підготовки та підвищення їх кваліфікації, а й покликана формувати у випускників вишів низку непрофесійних компонентів процесуально-діяльнісного характеру, зокрема формування вмінь цілісного сприйняття навколишнього світу та відчуття єдності з ним; цілісного сприйняття процесу і результату діяльності; оволодіння технологіями прийняття оптимальних рішень, вміння адаптуватися до різних змін, прогнозувати хід ситуації, яка може виникнути в результаті професійної діяльності; вміти попереджати їх негативні наслідки, оволодіння найважливішими загальнометодологічними принципами організації професійної діяльності та формування у випускників вишів толерантності в судженнях та своїй діяльності. Тобто

(с) Ліна Голуб, Євгенія Шаповал, 2019 
завданням сучасної вищої освіти $є$ формування конкурентноспроможності спеціалістів, основними професійними якостями яких повинні стати динамічність (професійна динамічність) та адаптованість особистості до умов мінливого середовища [1, с. 154-162].

Актуалізація такої проблеми вищої школи, як формування професійних компетентностей майбутнього вчителя фізичної культури зумовлена методологічною переорієнтацією змісту на сучасному етапі шкільної освіти на розвиток особистості учня: від того, яким буде майбутній учитель фізичної культури, чи виявлятиме він здатність брати до уваги вимоги суспільства до школи, залежить рівень психофізичної культури учнів.

Для формування тієї чи тієї компетентності у студентів педагогічного навчального закладу необхідно брати до уваги відмінності за рівнем їхньої компетенції у вирішенні кожного типу професійних завдань. Тому дослідники пропонують визначати рівень розвитку компетентностей так: чи буде випускник навчального закладу здатний вирішувати будь-які професійні завдання чи тільки ті, про які має певні уявлення.

Орієнтуючись на сучасні вимоги ринку праці, сучасна вища освіта до пріоритетів відносить не тільки набуття професійних знань майбутніми фахівцями, але і вміння оперувати знаннями, бути готовими пристосовуватися до нових потреб ринку праці, активно діяти, вміти швидко приймати відповідальні рішення в ситуаціях вибору, вирізнятися мобільністю, динамізмом, конструктивністю, здатністю до адаптації, умінням реалізувати свої творчі здібності та навчатися упродовж життя, фахівців із фізичного виховання [2, с. 19-24].

Аналіз досліджень дає право констатувати недостатній рівень сформованості професійної компетентності зокрема у молодих педагогів, що часто $€$ причиною проблем їхньої педагогічної реалізації в контексті формування професійної динамічності. Разом 3 тим, питання формування професійної динамічності (мобільності) та ії значення в процесі становлення професійної компетентності педагога, і вчителя фізичної культури, зокрема мало досліджено.

Mema cmammi - теоретичне обгрунтування педагогічних умов формування професійної динамічності вчителів фізичної культури та окреслення шляхів і засобів їі вдосконалення у системі вищої освіти.

Для досягнення мети передбачено виконання таких завдань:

- проаналізувати стан розробленості проблеми у вітчизняній і зарубіжній науковій літературі;

- уточнити сутність професійної динамічності майбутнього вчителя фізичної культури;

- визначити критерії та рівні сформованості професійної динамічності майбутнього вчителя фізичної культури;

- обгрунтувати ефективність педагогічної технології розвитку методології формування професійної динамічності майбутнього вчителя фізичної культури.

Відповідно до Національної доктрини розвитку освіти України у XXI столітті одним із завдань підготовки професійно компетентних педагогів, у тому числі і вчителів фізичної культури, $€$ формування їх соціокультурної компетенції, тобто професійної готовності педагога працювати в полікультурному середовищі, бути мобільним, здатним до адекватної взаємодії у ситуаціях повсякденного життя, підтримки професійних контактів [5, с. 4-6].

Зміст вищої педагогічної освіти в умовах компетентнісного підходу та суб'єкт-суб'єктних відношень передбачає набуття не лише певної суми знань, а, насамперед, формування умінь самостійно приймати рішення і швидко змінювати себе, адаптуватися до нових умов і вимог професійної діяльності. Це забезпечує динамічність (мобільність) професійності педагогів. Найбільш затребуваними на ринку праці будуть вміння навчатися впродовж життя, критично мислити, ставити цілі та досягати їх, працювати в команді, спілкуватися в багатокультурному середовищі, тобто бути мобільним у контексті вимог сьогодення [4].

Встановлено, що підгрунтям професійної компетентності майбутнього вчителя фізичної культури повинні слугувати спеціальна, а також соціальна та особистісна підготовка. Звідси випливає, що вдосконалення підготовки майбутнього вчителя фізичної культури знаходиться 
в прямій залежності не лише від правильної орієнтації студента в процесі навчання на спеціальних заняттях, але й від загальної методичної забезпеченості та практичної озброєності, одержаної у всьому різноманітті дисциплін, що вивчаються на факультеті фізичного виховання.

Усталене в педагогічній науці розуміння сутності та структури професійної компетентності майбутніх учителів фізичної культури дає нам змогу вважати, що вона включає мотиваційно-ціннісний, який надає спортивно-педагогічній діяльності яскраво вираженого особистісного характеру, та є чинником, що спонукає до професійної досконалості; когнітивно-пізнавальний уособлює процес знаходження нових знань про якості та властивості роботи в школі, усвідомлення значущості спортивно-педагогічної діяльності, розуміння, осмислення іiї поліфункціональних особливостей; діяльнісно-креативний компоненти $є$ складним багаторівневим регулятором поведінки і діяльності, що забезпечує мобілізацію і реалізацію його професійної динамічності з метою підвищення продуктивності спортивно-педагогічної діяльності [3, с. 53-64].

Встановлено, що процес формування мобільного фахівця передбачає організацію певного “поля можливостей”, освітньо-виховного середовища, життєдіяльності. Це орієнтує майбутнього спеціаліста на різноплановість вибору статусного росту, професійного розвитку, швидкої орієнтації (адаптованості), прагнення активно змінити несприятливі ситуації. Поза увагою вчених $є$ питання, пов'язані зі змістом, формами, методами і технологіями реалізації аспекту підготовки майбутнього учителя фізичної культури з метою формування його професійної мобільності та готовності до формування здоров'ятворчої компетентності школярів [7, c. 204-208].

Трактування методології пізнання професійної динамічності як процесу набуття студентами відповідних знань, умінь і навичок спортивно-педагогічної діяльності, а їі структури - як єдності трьох компонентів детермінує необхідність оцінювання рівня їхньої сформованості у студентів за мотиваційним, когнітивним і діяльнісно-творчим критеріями.

Мотиваційний критерій відображає професійну зорієнтованість студентів на професію вчителя фізичної культури. Когнітивний критерій застосовано для оцінювання наявності у студентів сукупності знань, потрібних для майбутньої професійної діяльності, та є домінантним серед інших груп критеріїв. Діяльнісно-творчий критерій забезпечує оцінювання готовності студентів до виконання завдань, пов'язаних із спортивно-педагогічною, організаційно-управлінською та фізкультурно-оздоровчою діяльністю дітей.

Із використанням розроблених критеріїв підтверджено гіпотезу про недостатній рівень розвитку професійної компетентності студентів-випускників вищих педагогічних навчальних закладів. Виявлено причини, що унеможливлюють професійний розвиток майбутнього вчителя фізичної культури: а) недостатня професійна мотивація студентів на початковому етапі навчання; б) неспрямованість традиційної професійної підготовки на розкриття багатоаспектної професійної діяльності, їі системного бачення; в) невідповідність навчальних програм і теоретичної та практичної підготовки студентів і непов'язаність таких видів підготовки, що зумовлено традиціями, інертністю; г) низький рівень професійної задоволеності, негативне ставлення до майбутньої професії [6, с. 244-253].

Унаслідок проведення констатувального експерименту на базі факультету фізичного виховання Полтавського анціонального педагогічного університету імені В.Г. Короленка виявлено педагогічні умови формування професійних компетентностей, зокрема методологію формування їх складової професійної динамічності:

- формування позитивної мотивації до спортивно-педагогічної діяльності, що спонукає до усвідомленої дії, формується в міру того, як людина враховує, оцінює, зважує обставини. Це дає змогу розглядати професійну динамічність як інтегративну основу зв’язку педагогічної діяльності й особистості вчителя фізичної культури, зважаючи на розуміння особистісно-діяльнісної сутності категорії професіоналізму; 
- забезпечення міждисциплінарних зв'язків в освітньому процесі вищого педагогічного закладу вищої освіти, що є перевагою використання освітніх нормативів як інформаційної основи інтегративно організованого освітнього процесу, створення реальних умов для розвитку в студентів інтегративного стилю мислення, що зумовлює продуктивність процесу формування такої багатоаспектної якості особистості студента, як професійна мобільність;

- послідовне стимулювання творчої реалізації студентів у соціокультурній діяльності на грунті вільного самовираження в спортивно-педагогічній діяльності. Активізація творчої діяльності студентів унаслідок наявності певної свободи дій дає змогу викладачеві разом зі студентами обирати найбільш перспективні шляхи досягнення поставлених цілей, а тим, хто навчається, провадити досить вільну творчу самостверджувальну діяльність.

Розроблено педагогічну технологію методології пізнання професійної динамічності майбутнього вчителя фізичної культури, відповідно до якої формувальний експеримент мав три етапи: мотиваційно-ціннісний, когнітивно-пізнавальний і діяльнісно-творчий.

Зважаючи на думку науковців, які стверджують, що зміст професійної динамічності можливо уявити у вигляді горизонтальної (здатність до виконання професійних функцій) та вертикальної (компетенції) складових і доводять, що эї формування повинно здійснюватися на основі певного комплексу організаційно-педагогічних умов з використанням принципу випереджувального рівня освіти, ми переконалися, що у процесі фахової підготовки має бути створено деякий запас наробок знань, способів діяльності на майбутнє для адаптації можливих змін у практичній професійній діяльності. Дана специфіка розглядається вітчизняними науковцями з погляду оптимізації, реформування й розширення своїх функцій, тому вона має складатися з перевірених практикою традиційних форм і методів, цінностей i здобутків фізичної культури і спорту, а з іншого боку - новаторських, пов'язаних з творчим, індивідуальним, особистісним підходом з використанням інноваційних технологій, серед яких - проектування, інтерактивні, креативні, комунікативні функції [2, с. 23-24].

Нинішньому динамічному суспільству потрібен фахівець, відкритий новому, здатний швидко адаптуватися до складних умов професійної і соціальної дійсності, самостійно й відповідально приймати рішення, зорієнтований на успіх та постійне самовдосконалення. Динамічність (мобільність) як один із невід'ємних показників професійної та соціальної зрілості суб'єкта є тією особистісною характеристикою, яка засвідчує внутрішню готовність людини до якісних змін, перетворень, зокрема у вимірах педагогічної дії як єдності цілей і змісту.

Узагальнення результатів проведеного дослідження дає підстави подати для вищих педагогічних закладів вищої освіти такі рекомендації: відмовитися від вузькофахового підходу в спортивно-педагогічній підготовці студентів на користь міждисциплінарного й інтегративного підходів, що відповідає науковій парадигмі фізкультурної освіти; створювати необхідні умови для заохочення викладачів до розроблення елективних спецкурсів і спецпрактикумів для студентів, які забезпечуватимуть особистісну мотивацію та прагнення до опанування майбутньою професією; уникати застосування антипедагогічних методів залучення студентів до творчої діяльності, шукати ефективні способи їхньої мотивації до творчої самореалізації.

Доведено, що завдяки застосуванню педагогічних технологій в освітньому процесі маємо змогу перемістити основний акцент з накопичення певного багажу знань до стимулювання особистісного та професійного розвитку студентів на основі становлення їхніх умінь самостійно вирішувати типові та нестандартні професійні та життєві завдання, актуалізуючи отримані знання, досвід діяльності й особистісні особливості.

\section{Список використаних джерел}

1. Вознюк О.В. Розвиток особистості педагога в умовах цивілізаційних змін: теорія і практика: Монографія. Житомир : Вид-вл ЖДУ ім. І.Я. Франка, 2013. 604 с. 
2. Кагиев А.К. Оптимизация содержания образования ан факультетах физического воспитания // Совершенствование профессиональной подготовки будущих учителей физического воспитиания. Пермь: ПГПИ. 1986. С. 19-24.

3. Максимчук I.А. Розвиток педагогічної майстерності майбутніх учителів фізичної культури в процесі професійної підготовки // Психологія розвитку особистості: теорія і практика: зб. Матеріалів науково-практичної конференції (м. Вінниця, 19 квітня 2016 р.). Вінниця : ТОВ “Нілан-ЛТД”. С. 53-64.

4. Меркулова Л.П. Формирование профессиональной мобильности специалистов технического профиля средствами иностранного языка: автореф. дис.... док. пед. наук: 13.00.08 [Электронный ресурс]. Самара, 2008. Режим доступу http://www.ceninauku. ru/info/page_18106.htm

5. Національна доктрина розвитку освіти України у XXI столітті // Освіта України. 2001. 18 липня. С. 4-6.

6. Никитин В.Н., Егорова 3.В. Проблемы формирования динамической конкурентноспособной личности (концепция целостного, системного, диалектического, синергетического подходов), Чебоксары, Научно-методический центр по подготовке кадров социальной службы, 2005. 391 с.

7. Шаповалова I. Формуванн фахової компетентності майбутніх учителів фізичної культури в контексті підготовки до професійного самовдосконалення, Педагогічний дискурс, 2014. Вип. 17. С. 204-208.

Modern society is characterized by rapid changes in all spheres of life, including the educational sphere as a fundamental component of the formation of individual's outlook. The development of education affect social integration processes, such as globalization, democratization, creating a unified information space. These changes led to the need to review and reform education at all levels, as the current system does not meet modern needs and require reorientation.

Knowledge and skills that future professionals acquire during their studies in higher educational institution are certainly important, but it is emphasized on the professional competence of the future teacher, which is determined by many factors, as competence, is defined by many specialists and experts as the indicators determining readiness for future professional life, further personal development and active participation in society. Focusing on the modern requirements of the labor market, the current higher education priorities relates not only on acquiring professional knowledge by future specialists, but also on their ability to operate knowledge, be prepared to adapt to the new needs of the labor market, to act, to be able to make quick responsible decisions in situations of choice, stand out mobility, dynamism, constructiveness, adaptability, ability to realize their creativity and learn to extend the life of specialists in physical education.

The priority task of modern education is a focus on competence approach, in which the educational purpose is to form future professionals' ability to mix professional fundamental basic knowledge on innovation thinking and effective practitioners, research approach to address specific educational issues based on universal ethical norms.

Training of future professionals at the university should provide formation of professional competence at the levels ensuring the successful formation of a highly competitive teacher of physical training.

Key words: professional competence, pedagogical technology, teacher of physical training, dynamism, pedagogical conditions, technological character of the process. 